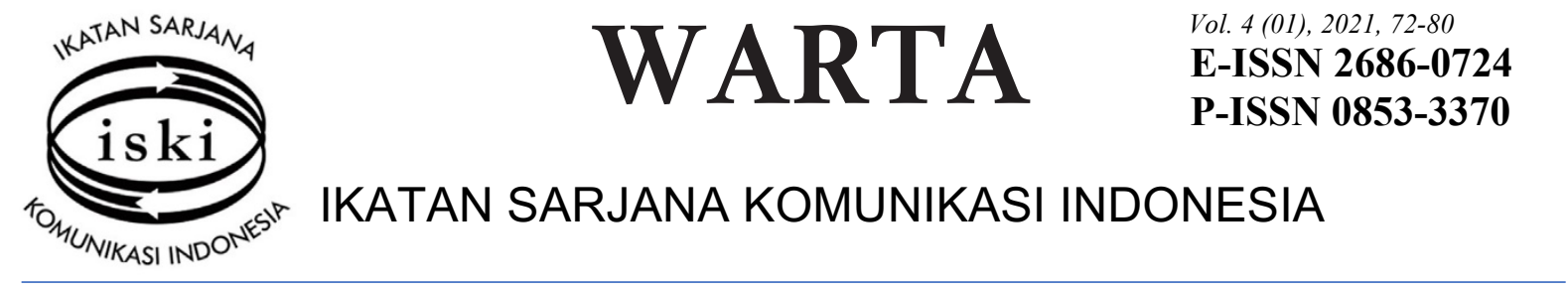

\title{
Model Komunikasi Interpersonal dalam Pelaksanaan Pelatihan Process Safety Management Berbasis Pengetahuan Karyawan
}

\author{
https://doi.org/10.25008/wartaiski.v4i1.103 \\ Masjuli $^{1 *}$, Poppy Ruliana ${ }^{2}$, Erna Fatmawati ${ }^{3}$ \\ ${ }^{1}$ Pascasarjana Universitas Sahid \\ Jl. Sudirman No. 86, Jakarta 10220 - Indonesia \\ ${ }^{2}$ Magister Ilmu Komunikasi Sekolah Tinggi Ilmu Komunikasi InterStudi \\ J1. Wijaya II No. 62, Kebayoran Baru, Jakarta 12160 - Indonesia \\ ${ }^{3}$ Universitas Negeri Jakarta \\ Jl. Rawamangun Muka Raya, Jakarta 13220 - Indonesia \\ *e-mail korespondensi: masjuli565@gmail.com
}

Submitted: 11/03/2021, Revised: 30/05/2021, Accepted: 20/06/2021

Accredited by Kemristekdikti No. 30/E/KPT/2019

\begin{abstract}
The development of diverse communication and information technology, which can take advantage of and reduce risk through the complexity of the communication model in Process Safety Management (PSM) and many companies in Indonesia consider PSM problems are minor problems that do not need to focus on implementing PSM specifically for employees. Because it is important to carry out employee knowledge based PSM training. The purpose of this research is to find out and describe the communication model in PSM training based on employee knowledge. The concept of interactive communication models in which the process takes place in two directions between two individuals or more who are participants in communication and interpretations occur to analyze the meaning of messages and realize the idea that communication is essentially a simultaneous circular process so as to cause understanding, understanding and knowledge of the employees. Descriptive qualitative research methods were used by involving informants who participated in the PSM training. Data collection was carried out through participant observation of in-depth interviews, and documentation and information retrieval via the website. The results showed that the interactive communication model in the PSM training took place effectively
\end{abstract}

Keywords: Communication, communication model, training, safety management process, knowledge,

\section{Abstrak}

Perkembangan teknologi komunikasi dan informasi yang beragam dapat memanfaatkan keuntungan dan mengurangi risiko melalui kompleksitas model komunikasi dalam Process Safety Management (PSM) dan banyak perusahaan di Indonesia menganggap masalah PSM adalah masalah ringan yang tidak perlu fokus untuk menerapkan PSM secara khusus kepada para karyawan. Oleh karena penting untuk melaksanakan pelatihan PSM berbasis pengetahuan karyawan. Tujuan penelitian ini adalah untuk mengetahui dan mendeskripsikan model komunikasi dalam pelatihan PSM berbasis pengetahuan karyawan. Konsep model komunikasi interaktif dalam prosesnya berlangsung secara dua arah antara dua individu atau lebih peserta komunikasi dan terjadi interpretasi untuk menganalisis makna pesan guna mewujudkan gagasan, merupakan proses melingkar secara simultan sehingga menimbulkan pengertian, pemahaman dan pengetahuan dari para karyawan. Studi ini menggunakan metode penelitian kualitatif deskriptif dengan informan yang mengikuti pelatihan PSM. Pengumpulan data dilakukan melalui observasi partisipan, wawancara mendalam, dokumentasi serta penelusuran informasi melalui 
website. Hasil penelitian menunjukkan, model komunikasi interaktif dalam pelatihan PSM berlangsung secara efektif.

Kata Kunci: Komunikasi, model komunikasi, pelatihan, proses safety management, pengetahuan

\section{PENDAHULUAN}

Hampir setiap organisasi atau perusahaan bisnis di Indonesia dihadapkan pada suatu situasi berhadapan dengan para karyawan, dan stakeholders karena memiliki latar belakang yang berbedabeda. Situasi seperti itu dapat menimbulkan tantangan, tetapi pada saat yang sama dapat bermanfaat bagi organisasi. Dalam perkembangan teknologi komunikasi dan informasi yang beragam, perusahaan dapat memanfaatkan keuntungan ini dan mengurangi risiko melalui kompleksitas model komunikasi melalui Process Safety Management (PSM). Masalahnya, banyak perusahaan di Indonesia menganggap PSM adalah masalah ringan dan tidak fokus menerapkan PSM.

Berdasarkan uraian di atas, perusahaan $\mathrm{X}$ yang karyawannya sering mengunjungi industri dan ikut pelatihan menganggap penting untuk mengikuti pelatihan PSM karena efeknya dapat menimbulkan pengetahuan, pemahaman dan pengertian karyawan atas materi pesan PSM. Mereka lantas dapat menilai apakah sudah menerapkan PSM dengan baik atau tidak. Itu karena individu memiliki perspektif dan pengetahuan yang berbeda dalam peralatan, proses, lingkungan, dan keselamatan. Selain itu, perspektif dan pengetahuan karyawan juga berbeda dari perusahaan ke perusahaan. Frekuensi pelatihan PSM untuk karyawan dan evaluasi PSM yang dilakukan di perusahaan dapat menjadi faktor penting untuk mempengaruhi PSM secara keseluruhan

Model komunikasi dari yang dominan ke yang alternatif dan digunakan secara terus-menerus, namun masalah tetap terjadi ketika mencoba menerapkan model komunikasi tertentu pada kelompok orang yang dipilih dengan latar belakang berbeda. Kurangnya kesadaran tentang model komunikasi dan tidak adanya kompetensi komunikasi dapat menjadi alasan mengapa orang-orang dari budaya yang berbeda tidak dapat menemukan bahasa yang sama. Akibatnya menimbulkan persepsi yang berbeda dan salah pengertian terhadap makna dari pesan yang disampaikan.

Beberapa penelitian digunakan untuk menyelidiki pertukaran pengetahuan tersebut yang dapat terjadi melalui sejumlah mekanisme berbeda, dan penggunaan teknologi informasi komunikasi, salah satunya dengan cara mengumpulkan pengalaman dan penyebaran pengetahuan (Gressgård, 2014).

Komunikasi berperan penting mensosialisasikan atau menginformasikan PSM yang dilakukan dalam bentuk pelatihan keterampilan komunikasi PSM, dengan melibatkan karyawan agar memiliki persepsi dan pengetahuan yang sama tentang PSM. Pelatihan dilakukan untuk menanggapi kesenjangan pengetahuan (pendekatan proaktif); menargetkan kelompok atau wilayah berisiko tinggi (pendekatan reaktif), dan untuk menyesuaikan persepsi risiko.

Untuk menanamkan sikap dan perilaku positif terhadap PSM, program proaktif harus dirancang dengan mempertimbangkan kebutuhan staf. Pelatihan dalam metode kerja yang aman harus melibatkan peningkatan kesadaran dan keterlibatan karyawan atas nilai-nilai yang sebenarnya terhadap kesehatan dan keselamatan. Perusahaan berupaya untuk meningkatkan keselamatan karyawan dan fasilitas. Untuk melakukan itu, penting melatih karyawan dan mengingatkan mereka terhadap pentingnya keselamatan kerja. Mereka juga mengundang instruktur untuk mengajar karyawan tentang teknik dan prosedur keselamatan peralatan baru dengan metode pelatihan bervariasi (Lee, 2018).

Sementara penelitian Gressgård (2014) menunjukkan, kepatuhan keselamatan dipengaruhi oleh penggunaan sistem pertukaran pengetahuan dan tingkat pertukaran pengetahuan dalam sistem organisasi, baik di dalam maupun di antara unit. Sistem penggunaan adalah prediktor yang paling penting, dan kepatuhan keselamatan tampaknya lebih kuat terkait dengan pertukaran pengetahuan dalam unit daripada pertukaran pengetahuan antarunit, dan itu dapat terjadi dengan menggunakan saluran komunikasi yang berbeda, baik formal maupun informal.

Selanjutnya, penelitian Vecchio-Sadus (2007), menunjukkan jaringan komunikasi menyediakan kerangka kerja yang kohesif dan suportif. Orang dan sistem kerja dapat berinteraksi secara sengaja dan kooperatif. Komunikasi keselamatan yang jelas dan konstruktif menyediakan mekanisme dengan pengetahuan dan pemahaman dapat ditingkatkan untuk mencegah perilaku berisiko dan untuk meningkatkan budaya keselamatan. Ini diilustrasikan oleh studi kasus yang menunjukkan bagaimana organisasi merespons penurunan kinerja karyawan cedera dengan berbagai teknik komunikasi keselamatan. 
Mekanisme komunikasi efektif sangat penting melibatkan karyawan dalam kegiatan keselamatan untuk mendapatkan dukungan guna mempertahankan budaya keselamatan yang positif. Mekanisme ini perlu melengkapi model komunikasi keselamatan praktis dan teknis. Karyawan dengan keterampilan komunikasi yang efektif lebih mampu memberikan umpan balik korektif untuk perilaku berisiko (sehingga mengurangi kemungkinan cedera) serta memberikan umpan balik penghargaan untuk perilaku aman. Dengan demikian meningkatkan kemungkinan perilaku di masa depan dilakukan dengan aman Vecchio-Sadus (2007).

Penelitian lain, menunjukkan bahwa komunikasi yang dijalankan di tempat kerja mampu memperbaiki perilaku tidak aman, kondisi tidak aman, menciptakan dialog terkait dengan perilaku aman dan tidak aman serta mampu memprioritaskan observasi berdasarkan tingkat risiko dan selanjutnya dapat menentukan tindakan koreksi hasil observasi dari pengamatan keselamatan kerja (Sulistyo, 2020).

Sementara itu, penelitian Gondowahjudi et al., (2018) menunjukkan, pelatihan komunikasi efektif yang diberikan dapat mendorong peningkatan pengetahuan karyawan sedangkan peneliti Alsamadani et al., (2013); Vecchio-sadus (2007) menyatakan komunikasi keselamatan dapat dimodelkan dalam berbagai jenis.

Dari berbagai studi terdahulu tersebut, penelitian yang kami lakukan ini mencoba melihat bagaimana model komunikasi interpersonal dalam pelaksanaan pelatihan process safety management berbasis pengetahuan karyawan di Perusahaan X. Adapun tujuannya adalah untuk mendeskripsikan model komunikasi pada pelatihan PSM berbasis pengetahuan karyawan yang diadakan.

\section{KERANGKA TEORI}

Komunikasi merupakan pertukaran makna secara terbuka, mengalir secara bebas. Interaksi yang sering dibahas dalam masalah keselamatan kerja secara signifikan mempengaruhi atribusi kecelakaan, perilaku keselamatan karyawan, komitmen keselamatan, dan kinerja keselamatan (Vinodkumar \& Bhasi, 2010). Jadi proses komunikasi keselamatan kerja bersifat dua arah (two way of communication) dan timbal balik karena menekankan pada interaksi. Oleh karena itu, model komunikasi yang digunakan dalam penelitian ini dan dianggap relevan dalam pelaksanaan pelatihan PSM berbasis pengetahuan karyawan. Model itu adalah model interaktif dari Schramm.

Pengertian model, menurut McQuail dan Windahl (1989) adalah "suatu tindakan yang merepresentasikan realitas, memilih unsur-unsur kunci, dan memperlihatkan adanya hubungan". Model memperlihatkan perkembangan bagaimana komunikasi berlangsung yang bisa dilihat dari perkembangan model komunikasi (Petersons \& Khalimzoda, 2016).

Penggunaan model komunikasi bisa menimbulkan penafsiran tentang fenomena dengan menggunakan struktur pesan tertentu yang mengkaitkan berbagai elemen dan hubungan yang ada diantara elemen-elemen komunikasi (Popescu, Pargaru, Popescu, Mihai, 2015).

Schramm memperkenalkan model interaktif untuk komunikasi dan percaya bahwa komunikasi adalah proses dua arah antara dua individu. Schramm juga menggunakan konsep "interpreter" untuk menganalisis makna pesan dan mewujudkan gagasan bahwa pada dasarnya komunikasi merupakan proses melingkar. Schramm mengerti decoding dan encoding sebagai aktivitas yang dikelola secara terus menerus atau simultan oleh pengirim dan penerima. Schramm juga membuat ketentuan untuk pertukaran pesan dua arah (Petersons \& Khalimzoda, 2016).

Sumbangan penting yang dibuat Schramm adalah mempertimbangkan bidang pengalaman, atau landasan bersama dari pengirim dan penerima. Pengirim menyandikan pesan sesuai dengan bidang pengalamannya. Bidang pengalaman penerima memandu proses decoding. Model ini mengasumsikan bahwa komunikasi melingkar dan umpan balik adalah fitur utama (Gambar 1).

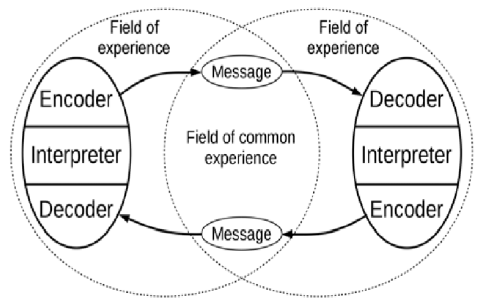

Gambar 1. Model Komunikasi Interaktif

Sumber: Wilbur Schramm. 
Dalam model di atas, encoder adalah siapa yang memulai dan mengirim pesan. Decoder adalah yang menerima pesan dan juru bahasa bisa berupa orang yang mencoba memahami dan menganalisis, memahami atau menafsirkan. Dari titik awal komunikasi hingga akhir, sebuah interpretasi terus berlanjut dan komunikasi antara dua individu sangat tergantung pada tumpang tindih antara bidang pengalaman keduanya.

Model ini mematahkan model pengirim dan penerima tradisional; setiap orang bertindak sebagai pengirim dan penerima dan karenanya menggunakan interpretasi. Pengkodean, simbol dan interpretasi berlangsung secara bersamaan. Gangguan semantik adalah konsep yang diperkenalkan di sini ketika pengirim dan penerima menerapkan makna berbeda pada pesan yang sama. Ini terjadi terutama karena kata-kata dan frasa tidak dapat dimengerti, sehingga kata-kata dan frasa tertentu menyebabkan adanya penyimpangan dari makna komunikasi yang sebenarnya (Petersons \& Khalimzoda, 2016).

Sementara itu, konteks dalam proses komunikasi digunakan untuk meningkatkan efektivitas komunikasi dari setiap upaya untuk meningkatkan pengetahuan, sikap dan perilaku. Konteks - konteks yang terjadi dalam proses komunikasi, menurut Mulyana (2007) untuk mengklasifikasikan konteks atau tingkatannya meliputi komunikasi:

(1) komunikasi intrapribadi, yakni komunikasi yang terjadi dengan diri sendiri; (2) komunikasi antarpribadi, komunikasi yang berlangsung di antara dua orang atau lebih dan besifat pribadi yang memungkinkan terjadi tanggapan secara langsung baik secara verbal maupun non verbal: (3) komunikasi kelompok, yaitu komunikasi yang terjadi di antara anggota suatu kelompok dengan tujuan yang sama, saling berinteraksi satu sama lain untuk mencapai kesepakatan bersama. Umpan balik dari komunikasi kelompok masih bisa diidentifikasi dan ditanggapi oleh para peserta lainnya; (4) komunikasi publik merupakan komunikasi yang terjadi dimana antara pembicara dengan khalayak; (5) komunikasi organisasi, merupakan komunikasi yang berlangsung dalam dalam suatu organisasi, baik formal maupun informal dalam jaringan yang lebih luas; (6) komunikasi massa, merupakan komunikasi dengan menggunakan media massa, baik media cetak maupun media elektronik dimana pesannya disampaikan secara serentak kepada khalayak.

Dari konteks komunikasi di atas, penelitian ini foku pada komunikasi intrapribadi, komunikasi antarpribadi, dan komunikasi kelompok karena konteks komunikasi ini dapat dilihat secara langsung bagaimana feedback terjadi dari komunikan pada pelatihan PSM.

Komunikasi keselamatan kerja yang efektif, menurut Vecchio-Sadus (2007) harus mencakup: (1) komunikasi dan diskusi terbuka mengenai masalah keselamatan dengan semua karyawan dari berbagai tingkatan dalam satu atau lebih organisasi; (2) mendorong perilaku aman dengan memberikan umpan balik; (3) menerapkan program pembelajaran untuk keselamatan.

Selain itu, mekanisme komunikasi yang efektif sangat penting melibatkan karyawan dalam kegiatan keselamatan, untuk mendapatkan kerja sama dan mempertahankan budaya positif (Cigularov et al. 2010). Akibatnya, komunikasi keselamatan kerja yang jelas dan konstruktif dapat meningkatkan pengetahuan keselamatan serta memberikan pemahaman yang lebih baik untuk mengurangi perilaku berisiko serta meningkatkan praktik kerja yang aman.

Sementara itu, Process Safety Management (PSM) menurut Occupational Safety Health Administration (OSHA) adalah alat analitis sistematis untuk mencegah pelepasan bahan kimia berbahaya, termasuk cairan dan gas beracun, reaktif, mudah meledak, dan mudah terbakar. Ini adalah manajemen komprehensif untuk mengurangi jumlah dan tingkat keparahan insiden yang berkaitan dengan pelepasan bahan kimia. Standar PSM ditetapkan oleh kombinasi standar federal dan nasional, arahan dan interpretasinya, teknologi terintegrasi, prosedur organisasi dan operasional, praktik manajemen, pedoman desain, program kepatuhan, dan metode lainnya (Abdul Majid et al., 2015).

Menurut Hardy, PSM umumnya mengacu pada penerapan prinsip dan sistem manajemen untuk mengidentifikasi, memahami, dan mengendalikan bahaya proses guna melindungi karyawan dan tempat kerja. PSM difokuskan pada pencegahan, kesiapsiagaan, mitigasi, respons terhadap, dan pemulihan dari pelepasan bahan kimia yang terkait dengan fasilitas. PSM didefinisikan sebagai semua penggunaan, penyimpanan, pembuatan, penanganan bahan kimia berbahaya (Hardy, 2013).

Ada 14 elemen dalam proses PSM yang dikeluarkan oleh OSHA yang harus dimiliki perusahaan: (1) Employee participation; (2) Safety Information Process, (3) Analysis of Hazard Processes; (4) Operating Procedures; (5) Training; (6) Contractors; (7) Pre-startup safety review; (8) Mechanical integrity; (9) Hot work permission; (10). Change Management: (11) Incident investigations; (12) 
Emergency planning and response; (13) Audit compliance; (14) Trade secrets (Hardy, 2013; HSE, 2005).

Semua elemen tersebut, saling ketergantung satu sama lain dan diperlukan untuk membuat seluruh citra PSM. Setiap elemen memberikan aliran informasi ke elemen lain untuk penyelesaian atau memanfaatkan informasi dari elemen lain untuk diselesaikan atau dicari solusi permasalahannya.

Pelatihan karyawan dilakukan sesuai dengan standar komunikasi bahaya OSHA. Karyawan diberitahu tentang bahaya bahan kimia dan membiasakan mereka membaca dan memahami material safety data sheet (MSDS). Namun, pelatihan tambahan dalam mata pelajaran seperti prosedur operasi dan praktik kerja yang aman, evakuasi, tanggap darurat, prosedur keselamatan, kegiatan otorisasi kerja rutin dan non-rutin, dan area lain yang berkaitan dengan proses keselamatan dan kesehatan perlu ditanggung oleh pimpinan program pelatihan.

Metode untuk mengevaluasi pelatihan harus dikembangkan bersama dengan tujuan dan sasaran program pelatihan. Evaluasi program pelatihan akan membantu perusahaan untuk menentukan jumlah pelatihan yang dipahami karyawan dan hasil yang diinginkan. Jika, setelah evaluasi, tampak bahwa karyawan tidak berada pada tingkat pengetahuan dan keterampilan yang diharapkan, pemberi kerja harus merevisi program pelatihan. Pemberi kerjan harus memberikan pelatihan ulang, atau memberikan sesi pelatihan penyegaran sampai kekurangan tersebut diselesaikan.

Mereka yang melakukan pelatihan dan yang menerima pelatihan juga harus diajak berkomunikasi tentang cara terbaik untuk meningkatkan proses pelatihan. Jika ada hambatan, harus diupayakan untuk meniadakannya, setidaknya harus menimimalisirnya.

Pertimbangan yang cermat harus diberikan untuk memastikan bahwa karyawan, termasuk karyawan tetap dan kontrak, menerima pelatihan yang selalu diperbarui. Jika perubahan dilakukan pada suatu proses, karyawan yang terkena dampak harus dilatih dan memahami dampak perubahan tersebut pada tugas mereka. Evaluasi penyerapan pelatihan karyawan akan menentukan kebutuhan untuk pelatihan lebih lanjut (dalam web U.S. Department of Labor, 2020).

Ada beberapa manfaat pelatihan PSM yaitu: (1) meningkatkan pengetahuan tentang penanganan pelepasan bahan kimia akan membuat seluruh organisasi menjadi tempat yang aman untuk bekerja; (2) PSM juga merupakan investasi keuangan yang cerdas, karena kecelakaan bahan kimia bisa sangat mahal; (3) mengambil tindakan pencegahan akan mengurangi kemungkinan down time dan kerusakan fasilitas yang sangat mahal untuk organisasi (web redfektor.com, 2020).

Dalam proses komunikasi, pengetahuan atau kognitif adalah efek dari komunikasi setelah diterpa pesan, terjadi suatu perubahan pada apa yang diketahui, dipahami, atau dipersepsi individu atau kelompok. Efek ini berhubungan dengan transmisi pengetahuan, keterampilan, kepercayaan (Ruliana, 2014). Pengetahuan adalah aset penting organisasi yang akan menciptakan nilai untuk meningkatkan keunggulan kompetitif organisasi dan tingkat keselamatan.

Pengetahuan adalah salah satu sumber terpenting untuk mencegah kecelakaan dan menjamin keamanan proses di industry kimia. Ada banyak definisi pengetahuan dalam domain manajemen pengetahuan. Pengetahuan adalah paduan dari pengalaman yang dibingkai dengan nilai-nilai, keahlian, informasi kontekstual dan wawasan yang menyediakan lingkungan yang cocok dan struktur untuk mengevaluasi dan menggabungkan informasi dan pengalaman baru (Chen, 2016). Informasi, pada gilirannya, menjadi pengetahuan ketika ditafsirkan, dimasukkan ke dalam konteks. Pengetahuan bukanlah data atau informasi, meskipun itu terkait dengan keduanya.

Pertukaran pengetahuan dapat dipahami sebagai kontribusi atau penerimaan informasi dalam melaksanakan tugas, cara atau metode kerja, pengetahuan dan saran, atau umpan balik tentang materi pelatihan PSM. Faktanya, pengetahuan mencakup data dan informasi, dan mengetahui cara menerapkan dan menggunakan informasi dan data.

\section{METODE PENELITIAN}

Paradigma penelitian ini adalah paradigma interpretif. Menurut Newman, interpretif bermula dari usaha untuk mencari keterangan mengenai fenomena sosial atau budaya berdasarkan perspektif dan pengalaman individu (Creswell, 2013). Studi ini menggunakan pendekatan kualitatif yakni pengetahuan dibentuk dengan menginterpretasikan berbagai perspektif dan masukan-masukan dari partisipan yang dilibatkan dalam penelitian.

Data didapat dari bermacam-macam sumber misalnya catatan lapangan, observasi, wawancara pengalaman individu, dan sejarah. Pendekatan penelitian ini yang digunakan relevan untuk 
menerangkan pandangan, sikap, dan pengertian dari orang yang memberikan informasi atau informan yang menjelaskan atau menginformasikan tentang PSM.

Metode penelitian yang digunakan adalah deskriptif untuk menggambarkan fenomena yang terjadi dalam kehidupan nyata (Yin, 2014). Ini sesuai dengan pendapat Bungin bahwa format deskriptif kualitatif umumnya dilakukan pada penelitian dengan bentuk studi kasus dan fokus pada unit tertentu dari berbagai fenomena (Bungin, 2010). Sementara itu, Marshal dan Rossman menyatakan descriptive research to explore the researchers' settings. Researchers enter the world of informants through continuous interaction, searching for key informants'meanings and perspectives (Creswell, 2007).

Penelitian ini melibatkan satu informan kunci yaitu GS yang memiliki keahlian dalam bidang Standardisasi K3 dan menjabat sebagai Kasubdit di Perusahaan X, dan enam informan yaitu para karyawan yang ikut dalam pelatihan PSM. Mereka dipilih karena memiliki keahlian dan kompetensi di bidang pekerjaan, seperti NZ memiliki keahlian dalam bidang Auditor ISO 9001, 17025, 18001, kemudian RS memiliki keahlian di bidang fire \& safety dan MN memiliki keahlian dalam bidang K3.

Informan lainnya TM, PSP, KT, memiliki keahlian dalam bidang K3. Latar belakang mereka penting untuk diketahui oleh instruktur sebelum melakukan komunikasi mengenai PSM.

Teknik Pengumpulan data dilakukan melalui observasi partisipasi, tahap kedua adalah wawancara mendalam (deep interview), tahap ketiga dokumentasi dengan data yang tersedia berbentuk suratsuratan, catatan, laporan, foto dan sebagainya. Data ini memberi peluang untuk mengetahui secara detail, seperti klipping, dokumen, company profile serta penelusuran data melalui online, seperti website atau server (Bungin, 2010). Untuk menganalisis data digunakan model Miles dan Huberman melalui tiga tahap yaitu tahap reduksi data, tahap penyajian data dan tahap kesimpulan atau verifikasi (Sugiyono, 2016).

\section{HASIL PENELITIAN}

Model yang digunakan dalam penelitian ini adalah model interaksional dari Schramm yang menggambarkan bahwa komunikasi adalah proses dua arah antara dua individu. Schramm juga menggunakan konsep "interpreter" untuk menganalisis makna pesan dan mewujudkan gagasan bahwa pada dasarnya komunikasi merupakan proses melingkar. Schramm mengerti decoding dan encoding sebagai aktivitas yang dikelola secara simultan oleh pengirim dan penerima; Schramm juga membuat ketentuan untuk pertukaran pesan dua arah.

Dalam model di atas, encoder adalah siapa yang memulai dan mengirim pesan. Decoder adalah yang menerima pesan dan juru bahasa bisa berupa orang yang mencoba memahami dan menganalisis, memahami atau menafsirkan. Dari titik awal komunikasi hingga akhir, sebuah interpretasi terus berlanjut dan komunikasi antara dua individu sangat tergantung pada tumpang tindih antara bidang pengalaman keduanya.

Penggunaan model komunikasi ini menimbulkan penafsiran tentang fenomena dengan menggunakan struktur pesan tertentu yang mengkaitkan berbagai elemen dan hubungan yang ada diantara elemen-elemen komunikasi. Dalam kaitannya dengan pelatihan PSM yang dilaksanakan oleh perusahaan X sebagai sumber komunikasi dimana karyawannya sering mengunjungi perusahaan, seperti kilang minyak maupun petrokimia yang menerapkan PSM sehingga para karyawan dapat mengamati penerapan PSM di industry sudah berjalan efektif atau tidak.

Dalam membangun program pelatihan, perusahaan X secara jelas mengidentifikasi karyawan yang akan dilatih, subjek yang akan dibahas, dan tujuan yang ingin dicapai. Tujuan atau sasaran pelatihan harus ditulis dalam istilah yang jelas dan terukur sebelum pelatihan dimulai. Sasaran ini perlu disesuaikan dengan masing-masing materi atau segmen pelatihan secara khusus. Instruktur harus menggambarkan tindakan dan kondisi penting di mana karyawan akan menunjukkan kompetensi atau pengetahuan serta pengetahuan apa yang dapat diterima.

Lingkungan pelatihan dapat diciptakan untuk membantu peserta pelatihan merasakan kenyataan penuh dari situasi tetapi dalam kondisi yang terkendali. Jenis pelatihan yang realistis ini bisa efektif dalam mengajarkan karyawan prosedur yang benar sambil memungkinkan mereka melihat konsekuensi dari apa yang mungkin terjadi jika mereka tidak mengikuti prosedur operasi yang ditetapkan.

Perusahaan X perlu mengevaluasi secara berkala program pelatihan mereka untuk melihat apakah keterampilan, pengetahuan, dan rutinitas yang diperlukan dipahami dan diimplementasikan dengan baik oleh karyawan mereka pada saat mengunjungi perusahaan yang menerapkan PSM. 
Konteks komunikasi dalam pelatihan PSM adalah komunikasi kelompok karena komunikasi terjadi di antara anggota suatu kelompok yang memiliki tujuan serupa, saling berinteraksi satu sama lain untuk mencapai kesepakatan bersama. Umpan balik dari komunikasi kelompok masih bisa diidentifikasi dan ditanggapi oleh para peserta lainnya (Mulyana, 2007; Ruliana, 2014).

Dalam prosesnya, encoder sebagai orang yang menyampaikan pesan, dalam hal ini instruktur terlebih dahulu merumuskan suatu pesan yang berisi tentang 14 materi PSM dan decoder-nya adalah para karyawan sebagai peserta pelatihan PSM. Selanjutnya encoder menegaskan maksudnya dengan merancang konten yang mengesankan, meneruskan pesan ke bagian kedua dan seterusnya selanjutnya mereka hanya merespons sesuai tujuan yang ingin dicapai. Di sini pengirim adalah anggota aktif dan penerima pasif (Petersons \& Khalimzoda, 2016).

Encoder yang menyampaikan pesan dinilai oleh para peserta memiliki keahlian dan pengalaman dalam bidangnya. Hal ini dikemukakan oleh TM, PSP, KT, RS, MN, RD dan NL peserta pelatihan PSM dengan mengemukakan intruktur memiliki keahlian dan pengalamannya sesuai bidangnya, khususnya memiliki pengalaman di bidang oil, gas dan penangangan bahaya.

Dari jawaban di atas dapat dikatakan, encoder menyandikan pesannya sesuai dengan bidang pengalaman dan keahlian yang dimiliki. Hal ini sesuai dengan apa yang dikemukakan oleh Schrannm untuk mempertimbangkan bidang pengalaman, atau landasan bersama dari pengirim dan penerima. Pengirim menyandikan pesan sesuai dengan bidang pengalamannya. Bidang pengalaman penerima memandu proses decoding.

Proses penyampaian pesan kepada decoder menguasi semua materi pesan yang tertuang dalam 14 elemen PSM. Menurut informan GS materi yang diberikan pada pelatihan PSM hanya fokus pada 13 elemen PSM, yaitu: Informasi Keselamatan Proses, Analisis Bahaya Proses, Prosedur Operasi, Praktik Kerja Aman, Pelatihan, Partisipasi Pekerja, Telaah Ulang Pra-Startup (TUPS), Keterpaduan Mekanik, Pengelolaan Kontraktor, Manajemen Perubahan, Tanggap Darurat, Penyelidikan Insiden, Audit Kepatuhan.

Ke-13 elemen tersebut disampaikan oleh encoder secara langsung tahapan dari masing-masing elemen yang ada di PSM secara informatif dan edukatif dengan bahasa yang mudah dimengerti dan dipahami. Hal ini dikemukakan oleh informan TM, PSP, KT, RS, MN, RD dan NL bahwa penggunaan bahasa yang digunakan oleh instruktur jelas dan terarah, walaupun menggunakan istilah asing tetapi dapat dimengerti karena sangat menguasai materi

Pernyataan para informan tersebut mengandung suatu makna, bahasa berperan penting dalam mentransfer pesan seperti yang dikemukakan Schramm, bahasa bisa berupa orang yang mencoba memahami dan menganalisis, memahami atau menafsirkan.

Oleh karena itu, para peserta pelatihan sebagai decoder benar-benar memperhatikan dan menyimak makna pesan yang disampaikan insttruktur dalam presentasi pemaparan materi dengan mengkombinasikan teori dan praktek dalam simulasi dan terjadi suatu diskusi yang sifatnya dua arah.

Media yang digunakan dalam pelatihan PSM memuliki pengaruh yang kuat karena visualisasi media mendeskripsikan fenomena atau peristiwa komunikasi yang terjadi, seperti video atau pun film. Informasi yang diperoleh dari informan TM, PSP, KT, RS, MN, RD dan NL mengemukakan media mendeskripsikan bagaimana interpretasi para karyawan terhadap suatu kasus kecelakaan jika tidak patuh pada keselamatan.

Secara visualisasi studi kasus yang disajikan menunjukkan bagaimana fokus pada elemen PSM tertentu dapat membantu mencegah kecelakaan atau bisa mengurangi dampak dari peristiwa yang tidak diinginkan. Dalam mendiskusikan kecelakaan, bukan untuk menyederhanakan kejadian dan kondisi yang menyebabkan kecelakaan atau menyalahkan individu atau organisasi. Jarang ada penyebab tunggal yang dapat diidentifikasi yang menyebabkan kecelakaan. Kecelakaan biasanya merupakan hasil dari faktor kompleks yang meliputi perangkat keras, perangkat lunak, interaksi manusia, prosedur, dan lingkungan.

Kecelakaan kerja dan insiden digunakan untuk menggambarkan di mana proses keselamatan dan proses manajemen gagal dalam beberapa cara. Decoder didorong untuk meninjau laporan investigasi kecelakaan secara lengkap untuk memahami kondisi dan rantai kejadian yang kompleks yang menyebabkan setiap insiden yang dibahas di sini.

Efek dari tayangan video mengenai kasus kecelakaan melahirkan berbagai interpretasi yang berbeda dari decoder, sehingga menimbulkan diskusi dalam bentuk dialog secara langsung karena 
tayangan tersebut mendeskripsikan pentingnya keselamatam dalam melakukan pekerjaan bagi karyawan dan dapat membangun pengetahuan mereka atas pentingnya PSM dan manfaat dari pelatihan PSM. Proses ini terus berlanjut sampai menemukan saling pengertian di antara instruktur dan peserta pelatihan, dengan kata lain proses berlangsung dari titik awal komunikasi hingga akhir, sebuah interpretasi terus berlanjut dan komunikasi antara dua individu sangat tergantung pada tumpang tindih antara bidang pengalaman keduanya dan tidak ada gangguan yang terjadi.

Dengan demikian dapat dikatakan pelatihan PSM berjalan dengan efektif karena sifatnya terbuka dan adanya umpan balik serta keinginan untuk menerapkan program keselamatan dan mekanisme komunikasi yang diterapkan sangat penting. Akibatnya, model komunikasi yang jelas dan konstruktif dapat meningkatkan pengetahuan dan memberikan pemahaman yang dapat mengurangi perilaku berisiko serta meningkatkan praktik kerja yang aman

Berdasarkan hasil penelitian dan pembahasan sebagaimana yang telah diuraikan di atas, maka temuan dalam penelitian ini adalah model transaksional dimana pengiriman dan penerima pesan yang berlangsung secara terus-menerus dalam sebuah episode komunikasi. Komunikasi bersifat transaksional adalah proses kooperatif: pengirim dan penerima sama-sama bertanggungjawab terhadap dampak dan efektivitas komunikasi yang terjadi dan diantara peserta komunikasi menimbulkan negosiasi makna.

\section{KESIMPULAN}

Kesimpulan penelitian ini adalah, PSM merupakan faktor penting pada Perusahaan X karena memberi karyawan pengetahuan dan alat untuk memahami risiko dalam bekerja dengan bahan kimia berbahaya. Konteks komunikasi dalam pelatihan PSM adalah komunikasi kelompok dengan penerapan elemen-elemen komunikasi dalam model komunikasi interaksional seperti encoder yaitu instruktur yang mengirimkan pesan memiliki keahlian dan pengalaman di bidangnya dan penyampaian pesan setiap elemen dalam PSM dapat dikuasai dengan baik.

Media yang digunakan seperti video dalam pemutaran film yang ditayangkan kepada orang yang menerima pesan yaitu decoder menimbulkan dialog atau diskusi dalam konteks komunikasi antarpribadi, sehingga sehingga menimbulkan pengertian dan pemahaman atas makna yang disampaikan, dan efeknya menimbulkan pengetahuan pada para peserta pelatihan. Dengan begitu, model komunikasi interaksional yang diterapkan berjalan efektit dan dapat dikatakan model komunikasi Schramm mendukung penelitian ini.

\section{DAFTAR PUSTAKA}

Abdul Majid, N. D., Mohd Shariff, A., \& Rusli, R. (2015). Process Safety Management (PSM) for managing contractors in process plant. Journal of Loss Prevention in the Process Industries. https://doi.org/10.1016/j.jlp.2015.06.014

Bungin. (2010). Penelitian Kualitatif: Komunikasi, Ekonomi, Kebijakan Publik, dan Ilmu Sosial Lainnya. Jakarta: Kencana. https://doi.org/10.1002/jcc.21776

Chen, M. (2016). Process Safety Knowledge Management in the Chemical Process Industry. American Journal of Chemical Engineering, 4(5), 131. https://doi.org/10.11648/j.ajche.20160405.16

Creswell, J. W. (2007). Research Design: Qualitative, Quantitative and Mixed Method Aproaches. SAGE Publications. https://doi.org/10.4135/9781849208956

Creswell, J. W. (2013). Qualitative Inquiry and Research Design. Qualitative Inquiry and Research Design.

Gondowahjudi, L. E., Ratri, D. R., \& Hakim, L. (2018). Pengaruh Pelatihan Komunikasi Efektif terhadap Peningkatan Pengetahuan Karyawan RSUD Kota Malang. Jurnal Ilmiah Administrasi Publik, 4(2), 100-105. https://doi.org/10.21776/ub.jiap.2018.004.02.2

Gressgård, L. J. (2014). Knowledge management and safety compliance in a high-risk distributed organizational system. Safety and Health at Work, 5(2), 53-59. https://doi.org/10.1016/j.shaw.2014.03.002

Hardy, T. L. (2013). Elements of Process Safety Management: Case Studies. Great Circle Analytics, $2-13$.

HSE. (2005). A review of safety culture and safety climate literature for the development of the safety culture inspection toolkit. The Health and Safety Executive, 1-42.

Lee, T. (2018). Process Safety Management: Optimized Models Influenced by Organization Culture 
Recommended

Citation.

https://scholar.rose-

hulman.edu/engineering_management_grad_theses/6

Mulyana, D. (2007). Ilmu Komunikasi: Suatu Pengantar, Bandung: Rosdakarya.

Petersons, A., \& Khalimzoda, I. (2016). Communication Models and Common Basis for Multicultural Communication in Latvia. Society. Integration. Education. Proceedings of the International Scientific Conference, 4, 423. https://doi.org/10.17770/sie2016vol4.1555

Ruliana. (2014). Komunikasi Organisasi:Teori dan studi Kasus. Jakarta: Rajawali pers.

Sugiyono. (2016). Memahami Penelitian Kualitatif. Bandung: Alfabeta.

Sulistyo P, B. (2020). Strategi Komunikasi dalam membentuk Budaya Keselamatan kerja melalui Implementasi Observasi PEKA (Pengamatan Keselamatan Kerja) di PT. X. Jurnal Kajian Ilmiah. https://doi.org/10.31599/jki.v20i1.66

Vecchio-Sadus, A. M. (2007). Enhancing safety sulture through effective communication. Safety Science Monitor, 11(3), 1-9.

Vinodkumar, M. N., \& Bhasi, M. (2010). Safety management practices and safety behaviour: Assessing the mediating role of safety knowledge and motivation. Accident Analysis and Prevention. https://doi.org/10.1016/j.aap.2010.06.021 